\title{
Background, Problems and Measures for Enterprises to Fulfill Their Environmental Responsibilities-From the Perspective of Xi Jinping's Thought of Ecological Civilization
}

\author{
Xuan Zheng, Qingjun Meng \\ School of Business, Hohai University, Nanjing, China \\ Email: xuan_zoe@126.com
}

How to cite this paper: Zheng, X. and Meng, Q.J. (2018) Background, Problems and Measures for Enterprises to Fulfill Their Environmental Responsibilities-From the Perspective of Xi Jinping's Thought of Ecological Civilization. Open Access Library Journal, 5: e4886.

https://doi.org/10.4236/oalib.1104886

Received: September 6, 2018

Accepted: September 23, 2018

Published: September 26, 2018

Copyright $\odot 2018$ by authors and Open Access Library Inc.

This work is licensed under the Creative Commons Attribution International License (CC BY 4.0).

http://creativecommons.org/licenses/by/4.0/

\begin{abstract}
In the new era, the construction of ecological civilization in China has been raised to a new strategic height, which puts forward stricter requirements and provides new impetus for enterprises to fulfill their environmental responsibilities. At present, there are still many problems when Chinese enterprises fulfill their environmental responsibilities. From the perspective of Xi Jinping's thought of ecological civilization, this paper analyzes the deep-seated reasons behind these problems and puts forward corresponding countermeasures for enterprises under the background of the construction of ecological civilization in China.
\end{abstract}

\section{Subject Areas}

Business Ethics and Corporate Social Responsibility, Environmental Economics

\section{Keywords}

Environmental Responsibility, Enterprises, Xi Jinping, Ecological Civilization Thought

\section{Introduction}

The ecological civilization construction in China has a history of more than ten years. The $17^{\text {th }}$ National People's Congress of the Communist Party of China in 2007 put forward the important proposition of building ecological civilization for the first time. In the $18^{\text {th }}$ National People's Congress, which was held in 2012, ecological civilization construction was first integrated into the overall layout of 
socialism with Chinese characteristics [1].

Since the $18^{\text {th }}$ National Congress of the CPC, Xi Jinping has paid close attention to the construction of ecological civilization in China. His innovative theory and profound practice have greatly enriched the theory of ecological civilization construction and formed Xi Jinping's ideological system of ecological civilization construction in the new era. The report of the $19^{\text {th }}$ National Congress of the CPC, with the theme of "speeding up the reform of ecological civilization system and building a beautiful China", put forward four important measures to build ecological civilization and emphasized a series of important concepts [2].

$\mathrm{Xi}$ Jinping's thought of ecological civilization is developed from ancient Chinese ecological wisdom and Marxist ecological civilization. Since ancient times, China has placed environmental protection in an important position in governing the country, and has developed a wealth of ecological philosophy. The excellent traditional Chinese culture, such as Confucianism's "harmony between man and nature", Taoism's "law of nature" and Buddhism's “equality of all living beings", is the spiritual wealth and important enlightenment of the development of ecological civilization. The dialectical view of nature and the view of social history contained in the Marxist view of ecological civilization are the ideological origin of the construction of ecological civilization in China, and also provide a scientific world outlook and methodology [3].

As the main body of the ecological civilization construction and the main participants in economic activities, enterprises play an important role in the construction of ecological civilization in China. At present, under the background of ecological civilization, Chinese enterprises have many problems in fulfilling their environmental protection responsibilities. Xi Jinping's thought of ecological civilization stands in a higher and newer perspective, which provides new ideas and methods to solve the problems and obstacles.

\section{The Meanings of Xi Jinping's Thought of Economical Civilization}

\subsection{Emphasizing the Construction of Ecological Civilization as the Key to the "Five-in-One" Overall Layout}

Xi Jinping's thought of ecological civilization elevates the status of ecological civilization construction to an unprecedented strategic height, which puts forward higher requirements for enterprises' environmental responsibility. Both historical experience and realistic challenges show that the ecological concept and green development is of great significance to national construction. The $18^{\text {th }} \mathrm{Na}$ tional Congress of the CPC put the construction of ecological civilization into the general "five-in-one" layout and explicitly wrote it into the Party Constitution, emphasizing the coordinated development of ecological civilization and economic, political, cultural and social construction [4]. Xi Jinping's thought of ecological civilization emphasizes that the construction of ecological civilization is an important part of the overall layout of socialism with Chinese characteris- 
tics in the new era.

\subsection{Emphasizing the Participation of Enterprises as Main Body and Government as Leading Body, and the Participation of Social Organizations and the Public}

Xi Jinping's thought of ecological civilization clearly states that there are three main participants in the implementation of the environmental governance system: the government is the dominant, enterprises are the main participants, and social organizations and the public participate together. As the main participant of the socialist market economy and the direct undertaker of social production and circulation, enterprises should be the main body of ecological civilization. In their economic activities, enterprises must fulfill their responsibilities and play an active and self-restraining role. The government should strengthen its commanding and supervising role by improving the performance appraisal. As an indispensable part of ecological civilization, social organizations and the public should fully mobilize the enthusiasm to protect the environment, and let public opinion play a supervisory role [5].

\subsection{Taking "Two Mountains Theory" and "Environmental Productivity" as Important Base Points}

Xi Jinping's thought of ecological civilization is an important interpretation of the relationship between economic development and environmental protection, which provides a basis for enterprises to change the concept of development. In the early years of reform and opening up, economic development and environmental protection are incompatible opposites. Enterprises damaged the ecology and sacrificed the environment for production and profit. This concept of "changing the environment for development" has paid a huge price. Xi Jinping creatively put forward the important idea that "green water and green mountains are golden mountains and silver mountains", and solved the difficult problem of how to look at the relationship between economic development and environmental protection, which reveals that a good ecological environment can create economic value.

\subsection{Taking "System Engineering Thinking" and Strict Ecological Protection System as the Guarantee}

Xi Jinping's thought of ecological civilization integrates rich practical experience and puts forward system approach and institutional requirements for the fulfillment of environmental responsibilities. First, Xi Jinping emphasized the idea of systematic engineering to promote the construction of ecological civilization. The management of ecological environment needs cooperation and coordination from superiors to subordinates and multi-pronged approaches to complete. The construction of ecological civilization cannot be simply separated from other construction. Second, to do a good job in the construction of ecological civilization, we must bring it into the orbit of institutionalization and legalization. Xi 
Jinping said: "Only the most stringent system and the most stringent rule of law can provide a reliable guarantee for the construction of ecological civilization" [6].

\section{Problems in the Environmental Responsibilities of Enterprises}

\subsection{Enterprises Lack Sense of Responsibility for Environmental Protection}

In recent years, the environmental protection departments have exposed the lack of environmental awareness of some enterprises during inspections. High-level leaders of enterprises lack the concept of environmental protection, and there is a narrow concept of pursuing profit maximization while ignoring environmental protection investment. Secondly, employees in enterprises do not know what "environmental responsibility" is. The employees may lower the standard of work in the implementation of environmental protection, causing environmental loopholes everywhere.

The lack of environmental awareness of enterprises reflects that the propaganda and education of ecological civilization should be strengthened in the whole society. At present, the connotation of environmental protection has not yet reached a consensus among enterprises. Many enterprises did not realize the positive significance of environmental protection for their own and social development.

\subsection{Enterprises Lack Environmental Protection Investment}

Compared with developed countries, Chinese companies' investment in environmental protection is rather insufficient. According to the National Environmental Statistics Bulletin 2011-2015 issued by the Ministry of Environmental Protection, the total investment in environmental pollution control accounted for only $1.45 \%$ of GDP on average during the $12^{\text {th }}$ Five-Year Plan period. At present, the investment in environmental pollution control in China is mainly supported by government funds, and the investment of enterprises is less than one third of the total investment.

The high cost of environmental protection and the imperfect incentive mechanism of the government are the reasons for the insufficient investment. On the one hand, the amount of environmental investment is large and the effect is slow, so many companies are often difficult to undertake. In order to meet higher emission standards and increasingly stringent environmental requirements, enterprises are facing rising environmental responsibility costs. Taking Baosteel as an example, in 2016, the cost of the company's environmental protection is 3.977 billion yuan, accounting for $43 \%$ of the net profit of the year. On the other hand, the imbalance of government incentive mechanism results in low enthusiasm for environmental protection. There is a phenomenon of uneven distribution of government environmental protection incentives. Some areas lack incen- 
tive measures, thus enterprises cannot get sufficient support from the government [7].

\subsection{The Quality of Disclosure of Environmental Information Is Low}

The environmental information disclosure of enterprises in China is characterized by low quantity and low quality. According to the "China Listed Companies' Environmental Responsibility Information Disclosure Evaluation Report" issued by the China News Association, only $26.62 \%$ of the listed companies in China issued environmental information reports in 2015. The quality of these published reports is also mixed. A 2017 study by the Center for Environmental Economics and Research of Fudan University showed that 13 industries in the sample scored below 50, and the level of environmental information disclosure was very low. The reports use more subjective qualitative descriptions with low credibility, and the main data disclosed lack of detail and description.

The reason for this phenomenon is that China has not yet established a perfect system and criteria for mandatory disclosure of environmental information. Laws and regulations do not put forward rigid requirements, and enterprises only voluntarily disclose environmental information for the promotion of social concern; environmental information disclosure related laws and regulations are not detailed enough, lacking of unified and comprehensive criteria. What is more, some industries did not give clear information disclosure guidelines, resulting that the quality of information disclosure in the industry is far behind the overall level [8].

\section{Measures to Promote Enterprises to Fulfill Their Environmental Responsibilities}

\subsection{National Level: Coordinating Top-Level Planning and Improving Laws and regulations}

Under the top-level design of the CPC on the construction of ecological civilization, government planning at all levels needs to be organic convergence. Governments at all levels should formulate special plans for the environmental protection work of enterprises, educate enterprises' environmental concepts, construct the system of environmental protection with enterprises as the main body, and strengthen the environmental supervision and enforcement of enterprises.

In view of the lack of legislation in China, we should enhance the binding effect of laws and regulations on the environmental responsibility of enterprises. The cost of environmental violations should be raised by strengthening the legal restraint of environmental information disclosure, improving environmental tax and increasing punishment. In addition, the government should improve the policy of environmental subsidy and environmental incentives to alleviate companies' financial pressure caused by huge investment in environmental protection. Utilizing the dual functions of environmental protection tax and environmental innovation subsidy, we can construct the environmental regulation sys- 
tem which can encourage enterprises' innovation in environmental protection.

\subsection{Environmental Sector: Concentrating all Forces and Intensifying Law Enforcement}

The Ministry of ecology and environment, as China's environmental monitoring agency, is the main force of environmental law enforcement in China. To clarify the powers and responsibilities of environmental law enforcement departments, we should define the leadership of the Ministry of Ecological Environment and concentrate the strength of other departments. The environmental department should also improve the rigid means of law enforcement and improve the efficiency. We should change the current situation of environmental law enforcement which relies on penalty instead of management. We should strictly implement such means of punishment as seizure, daily fines, suspension of construction, closure of business and administrative detention so as to enhance the deterrence of law enforcement measures and raise the cost of environmental violations by enterprises. Only when the illegal cost of enterprises is higher than the cost of environmental protection, can the enthusiasm of enterprises to invest in environmental protection be greatly enhanced.

In addition, China's environmental law enforcement work still needs to make good use of the important impetus of public opinion and mobilize the power of the media and the public, so as to play the role of supervision and guidance of public opinion.

\subsection{Enterprises' Level: Increase Environmental Investment in All Aspects and Links}

Enterprises should invest more in environmental protection and do a good job in green planning, environmental internal management and green technology innovation.

First, the enterprises need to be guided by green strategy and environmental protection planning. China's Environmental Protection Law stipulates that: "Units that produce environmental pollution and other public hazards must incorporate environmental protection into their plans and establish environmental protection responsibility system". As the main body of the construction of ecological civilization, enterprises should pay close attention to national policies and compile environmental responsibility plans according to the national ecological civilization development program. Second, we should strengthen the internal management of the environment and establish the internal environmental responsibility management system. While realizing the business objectives of the enterprise, environmental design and control should be strengthened in product research and development, procurement, production, sales and recycling. Third, enterprises should increase investment in green products, environmental facilities and equipment, energy saving and emission reduction technology, and expert professionals. Then they can gradually optimize the structure of products and form the core competitiveness centered on green technology. 


\subsection{Social Level: Seeking Diversified Participation and Multilateral Cooperation}

The promotion of enterprises' environmental responsibility must actively seek the participation and cooperation of all social forces.

First, give full play to the role of the market in the allocation of resources. Improve the market-oriented ecological governance mechanism by establishing a clear property rights trading market. The promotion of corporate environmental protection responsibilities must actively seek the participation and cooperation of all sectors of society. Promote the development of green finance, establish a market-based incentive mechanism, and guide the flow of social funds to green industries. The second is to strengthen cooperation between the government and enterprises. Develop a PPP model for environmental projects and introduce social capital into environmental governance projects. The government can also share environmental responsibility with companies to reduce the pressure on pollution control. The third is to build a platform for cooperation between enterprises and other institutions, such as universities, scientific research institutions and social organizations. Companies' can combine their environmental needs with the relevant research fields of universities to achieve complementary advantages. At the same time they can also strengthen alliances with other companies, so as to concentrate resources and jointly develop projects and construction engineering laboratories. The fourth is to seek international cooperation, the government could establish an international alliance for green development, and promote cooperation in technology and finance.

\section{Conflicts of Interest}

The authors declare no conflicts of interest regarding the publication of this paper.

\section{References}

[1] Yang, W.J. (2013) From Sustainable Development to Building a Beautiful China: Evolution and Realization Path of the Party's Thought on Ecological Civilization Construction. Exploration, 4, 4-8.

[2] Xi, J.P. (2017) Deciding to Build a Well-Off Society in an All-Round Way and Win the Great Victory of Socialism with Chinese Characteristics in the New Era-Report at the 19th National Congress of the Communist Party of China. People's Daily, 2017-10-28.

[3] Deng, K.J. and Li, G.X. (2010) On Marxist View of Ecological Civilization. Philosophical Research, 5, 23-27.

[4] Wang, G. (2018) Promoting Ecosystem Civilization through Systematic Thinking. People's Daily, 2018-2-9.

[5] Yang, J. (2017) Promoting the Construction of Ecological Civilization and Striving for a New Era of Socialist Ecological Civilization. Administrative Reform, 10, 4-11.

[6] Xi, J.P. (2013) Adhere to the Basic State Policy of Saving Resources and Protecting the Environment, and Strive to Move towards a New Era of Socialist Ecological Civilization. People's Daily, 2013-05-25. 
[7] Qiao, Y.B. (2013) Increase Investment in Environmental Protection and Control Environmental Pollution. Environmental Protection, 17, 39-41.

[8] Zhang, J.Z., Li, H.Y. and Li, T. (2017) Reflections on Improving the Environmental Information Disclosure System of Listed Companies in China. Environmental Protection, 20, 36-39. 